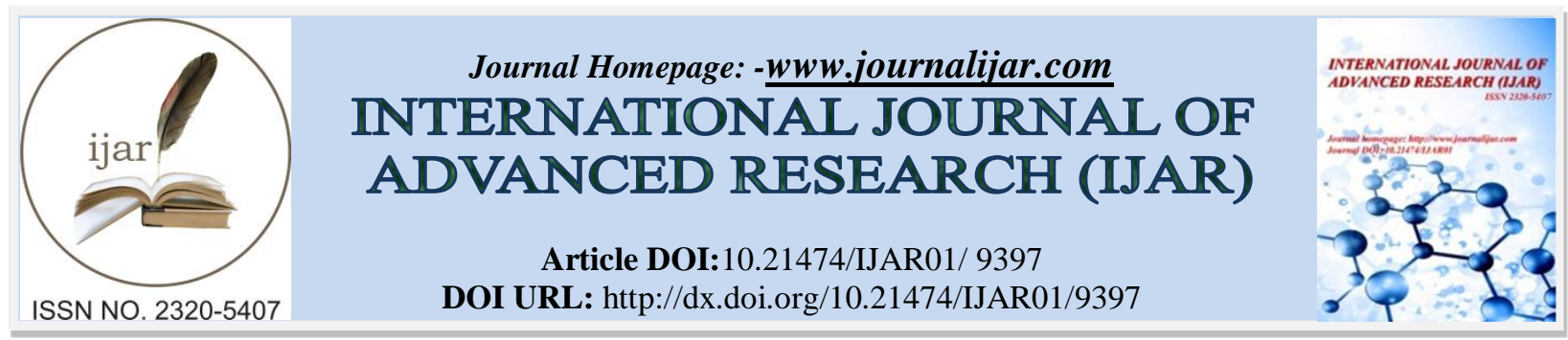

RESEARCH ARTICLE

\title{
A COMPREHENSIVE AND COMPARATIVE VIEW OF GUNAS IN AYURVEDA AND VAISESIKA PHILOSOPHY.
}

\section{Dr. Shruti Patel ${ }^{1}$, Dr.Vijay Vitthal Bhagat ${ }^{2}$ and Dr. Krishna Rathod ${ }^{3}$.}

1. Post Graduate Scholar,Co-Guide (Dept. of Samhita Siddhant) Parul Institute of Ayurved, Parul University.

2. Associate Professor and Guide, Co-Guide (Dept. of Samhita Siddhant) Parul Institute of Ayurved, Parul University.

3. Assistant Professor and Co-Guide (Dept. of Samhita Siddhant) Parul Institute of Ayurved, Parul University.

\section{Manuscript Info}

(.........................

Manuscript History

Received: 17 May 2019

Final Accepted: 19 June 2019

Published: July 2019

Key words:-

Ayurveda, Guna-Nirupana (Properties,

Qualities, Character).

\section{Abstract}

It has been a questioned of what is the necessity of teaching of Padarth Vigyana, specifically Darshana (Indian Philosophies) Shastras in the syllabus of Ayurvedacharya course. Ayurveda is a Sarvadarshanparishada shastra which means this system of health science is related to various darshanas. These may be considered as factors influencing the general gunas and hence may be considered as accessory and Yukti, Abhyasa and Samskara are not considered in Vaisesika Darsana.There are similarities of some concept of ayurveda and Vaishesika darshan shastra, but as the prayojana (aim) of both Shastra are same into some extent as maintenance of healthy situation in body and mind that is physical, mental and spiritual wellbeing of individual. These aims, these Shastra have been advocated in a different way.

The Visesika Dharsana also considers these two aspects, but the meaning and application are not similar to Ayurveda. In fact Ayurveda has applied these two in a wider connotation.

Copy Right, IJAR, 2019,. All rights reserved.

\section{Introduction:-}

Guna stands for properties or qualities possessed by a Dravva. It is defined as that factor which has invariable concomitance with Dravya, does not act, nor is an action, but a cause in the production of respective property in another drug.' Susruta does not define it. These properties may be physical or pharmacodynamic. The pharmacodynamic properties are identified by the action of a drug on the body (by inference). According to Caraka Samhita, there are 41 Gunas as are seen below:

Table No. 1:-Classification of Gunas

\begin{tabular}{|c|c|c|c|}
\hline $\begin{array}{l}\text { Sabdadi-5 } \\
\text { properties) }\end{array}$ & $\begin{array}{l}\text { Gurvadi-20 } \\
\text { properties) }\end{array}$ & $\begin{array}{l}\text { Buddhyadi-6 } \\
\text { qualities) }\end{array}$ & $\begin{array}{l}\text { Paradi-10 } \\
\text { (General) }\end{array}$ \\
\hline 1. Sabda & & 4. Rasa & \\
\hline
\end{tabular}

Corresponding Author:-Shruti Patel. 
These represent the special properties of Pancamahabhuta. They are perceivable directly by jnanendriyas (sense organs) and therefore, are also called Indiriyarthas (sense objects).

Table No 2:-

\begin{tabular}{|l|l|}
\hline 1. Guru (heavy) & 2. Laghu (light) \\
\hline 3. Sita (cold) & 4. Usna (hot) \\
\hline 5 Snigdha (oily) & 6. Ruksa (dry) \\
\hline 7. Manda (indolence) & 8 Tiksna (fiery), \\
\hline 9. Sthira (stable) & 10. Sara (mobile) \\
\hline 11. Mrdu (softness) & 12. Kathina (hardness) \\
\hline 13. Visada (nonsliminess) & 14. Picchila (unctousness-slimy) \\
\hline 15. Slaksna (smooth- ness-shiny) & 16. Khara (roughness) \\
\hline 17. Suksma (subtle) & 18. Sthola (big/gross) \\
\hline 19. Sandra (dense) & 20. Drava (fluid) \\
\hline
\end{tabular}

The above are mutually opposite qualities. These are self explainatory. These properties are both physical and pharmacodynamic, in Ayurveda. Descriptions in terms of these properties with reference to dietary substances, herbs and minerals, medicinal compounds, Dosha-Dhatu-Mala of the body are found in abundance.

Table No. 3:-

\begin{tabular}{|l|l|}
\hline 1. Buddhi (intellect) & 2. Iccha (desire) \\
\hline 3. Dvesa (hatred) & 4. Sukha (happiness) \\
\hline 5. Duhkha (misery) & 6. Prayatna (efforts \\
\hline
\end{tabular}

These constitute Adhyatmika Gunas. These are the attributes of soul who is in touch with the mind and the body. Pure soul (conciousness) has no attributes according to Ayurveda also.

Table No 4:-

\begin{tabular}{|l|l|}
\hline 1. Para & 2. Apara \\
\hline 3. Yukti & 4. Sankhya \\
\hline 5. Samyoga & 6. Vibhaga \\
\hline 7. Prthaktva & 8. Parimana \\
\hline 9. Samskara & 10. Abhyasa \\
\hline
\end{tabular}

These are Paradigunas.

\section{Sabdadi (Sarthadi)Gunas}

Ayurveda considers that the entire body is a compound of Pancamahabhutas and hence every part of it has gunas pertaining to mahabhutas. These Pancamabhutagunas are detectable both in normal and abnormal conditions and hence they are useful in the diagnosis of disease. The scopes of these Gunas are not strictly limited to the knowledge of the physical status alone, but are also useful in the identification of medicinal drugs (herbs/minerals) and food articles conducive to health. Thus it is essential to know these properties in detail.

\section{Sabdadi (Sarthadi) Gunas}

Sabda (sound), Sparsa (touch), Rupa (vision), Rasa (taste), Gandha (smell) are the special properties attributed to Akasa, Vayu, Tejas, Ap, Prthvi Mahabhutas respectively. In the evolutionary stage according to Sankhya the preceding subtle stage of Mahabhutas is called Tanmatra which are synonymously termed as Suksmabhutas in Caraka Samhita - A notable point focussed in pages to come. These Tanmatras are individually named after these Gunas viz. Sabda tanmatra - Sparsa tanmatra - Rupa tanmatra -Rasa tanmatra and Gandha tanmatra. These Tanmatras are called either Guna or Suksma-bhutas in Caraka Samhita. The term Tanmatra is however used in Susruta Samhita.

These Tanmatras originally in an isolated individual subtle form possess these Sabdadi Gunas isolatedly and respectively as follows: 
Table No 5:-

\begin{tabular}{|l|l|}
\hline Tanmatra & Gunas(Attributes) \\
\hline Sabda & Sabda guna only \\
\hline Sparsa & Sparsa guna only \\
\hline Rupa & Rupa guna only \\
\hline Rasa & Rasa guna only \\
\hline Gandha & Gandha guna only \\
\hline
\end{tabular}

These Tanmatras while getting transformed into Mahabhutas, the first one (Akasa mahabhuta) will have only one attribute i.e. Sabda and thereafter the number of Gums goes on increasing successively till Prthvi mahabhuta is formed. The attributes of preceding ones will be added to those of the succeeding ones respectively.

Table No 6:-Showing the Formation of Mahabhutas from Tanmatras

\begin{tabular}{|r|l|l|}
\hline Sr. No. & Tanmatra & \multicolumn{1}{c|}{ Mahabhutas } \\
\hline 1 & -- & Akasa - Sabda, Guna only \\
\hline 2 & Sabda + Sparsa & Vayu - Sparsa, Sabda, Guna \\
\hline 3 & Sabda + Sparsa + Rupa & Tej - Rupa, Sparsa, Sabda \\
\hline 4 & Sabda + Sparsa + Rupa+ Rasa & Jala - Rasa, Rupa, Sparsa, Sabda \\
\hline 5 & Sabda + Sparta + Rupa + Rasa + Gandha & Prthvi -Gandha \\
\hline
\end{tabular}

In the evolution of the atom of any Mahabhuta, corresponding subtle Bhuta acts as the central radical, while all the other subtle Bhutas form the peripheral structure. Eg. For the evolution of Jalamahabhuta atom the corresponding subtle Bhuta (Tanmatra) is Rasatanmatra and this forms the radicle while the others viz

Sabda + Sparsa + Rupa tanmatra form the periphery.

Sabdah sparsasca rupam ca raso gandhasca tad gunah!

tesamekagunah purvo gunavrddhilh pare pare;

purvah purvagunascaiva kramaso gunisu smrtah (C. Sa. 27-28)

As all the physical matters are composed of these basic elements (mahabhutas) they are supposed to possess all the Sabdadi five Gunas, but express manifestation of any one or two or more Gunas in any particular material is owing to the dominance of certain corresponding Mahabhuta responsible for such manifestive expressions.

These Sabda gunas help not only identification of drugs but also basic Bhoutika structural identity of a given drug (predominance of corresponding Bhutas may be identified).

\section{Sabda Guna}

This is the inherent Guna of Akasa and is directly percieved by ears. The term Sabda is also used in "Vadamargapada" discussed earlier, but a different context. Ayurveda had known that, normally sounds are produced in certain systems of the body and under certain abnormal conditions also sounds are produced that are audible. Sounds described in Ayurveda also include the natural sound, 'Svara' (voice). Normal human voice is compared with the voice of swan, crane, wheel, kettledrum, housesparrow, crow, dove etc. and abnormal qualities of voice are stated as feeble, inaudible, indistinct, hoarse, stammering etc. A spontaneous manifestation of any abnormal voice, in an individual without any known detectable cause indicates imminent death.

For example, Normal/abnormal sounds in the heart, lungs, intestines, joints, snoring, voice of animals, music, sound while passing stools or flatus, in flowing, water, blowing wind and so on. The clinical applicability of Sabdaguna has already been discussed earlier under Sabdapratyaksa.

\section{Sparga Guna}

This is inherent Guna of Vayu mahabhuta. That factor which is cognisible by skin is sprasa guna. Sita-Usna, KharaSlaksna, Mrdu-Kathina, Snigdha-Ruksa, Sandra-Drava, Sthira-Sara (Cala), Suksma-Sthula, Visada-Picchila are gunas which are cognoscible to Sparsanen-driya and hence constitute Sprasa gunas.In many diseases pertaining to viscera and also in the qualitative identification of drugs, examination of these Gunas play a significant role. Eg: Duhsparsa, Khara-sparsa, Kharapatra etc. 
For example, all the tactile qualities such as hot, cold, unctuous, slimy, rough, dry, wet etc. come under this category only. Tactility itself is a basic quality possessed by a material which is perceived by the skin in various kinds such as above. Its applicability in Ayurveda has been amply demonstrated earlier tinder Sparsanendriyapratyaksa.

\section{Rupa Guna}

This is an inherent guna of Tejo mahabhuta which is cognisible by the eye. Although colour is an important aspect of Rupa other aspects like the shape, size, movement, complexion, shadow's etc., are also no less important, as these are very useful in the identification of many drugs and diseases as well.

For example: Visibility is a basic quality possessed by a thing perceived by the sense of vision. This may be perceived in different kinds of definite nature such as colour, shape, size, movements etc as are applicable to a given thing. This is widely applied in Ayurveda to identify drugs, diet, diseases and various other factors which fall under broad spheres of health and ill-health. Its utility and practical applicability have been amply illustrated under Darsanendriya pratyaksa

VaisesikaDarsana also considers Rupa as a Guna, owing to Tejas. Prasastapada mentions that there are colours like Sukla-Nila etc. A very general description alone is provided here without referring to normal or abnormal colour of any substance. Pramana (quantity or size), Akrti (shape), Chaya (complexion), Prakrti-vikarah (abnormal gait, abnormal chest and abnormal movements etc.) aspects of Rupa gunapercieved by Caksurindriya, as envisaged by Ayurveda is not found specifically mentioned under Rupa in VasesikaDarana.

\section{Rasa Guna}

This is referred to such of the basic quality possessed by a material which can be perceived by Rasanedriya alone and not by any other sense. This is again perceived in different kinds such as Sweet, Sour, Salt, Bitter, Pungent and Astringent. These tastes (Rasas), though qualities themselves, are stated to be always associated with some specific Gurvadigunas (see Table) also (not substratum to Gurvadigunas). They are very important constituent properties possessed by any medicinal/non medicinal/herbs/food articles, in the perspective of the pharmacodynamic /biodynamic actions of the concerned drug/ food on the bodily tissues, bioenergies of the living body.

This is the basic quality of Jalamahabhuta. This is cognoscible he the sense of taste (Rasanendriya) only. There are six tastes to which the tongue can identify. Rasa guna forms one of the main tools to identify the herbs, medicinal preparations, food and many other bodily materials as well. Rasaguna in Ayurveda plays an important role in explaining biodynamics or pharmacodynamics of food articles and drugs of medicinal value.

Influence of each Rasa on health and ill-health has been widely described in all the three major Ayurvedic Texts (Brhattrayi). A glance at the following table demonstrates the effects of each on health and ill-health.

Table No 7:-

\begin{tabular}{|c|c|c|}
\hline Taste & $\begin{array}{l}\text { Positive effects on health when } \\
\text { used in proper proportion }\end{array}$ & $\begin{array}{l}\text { Negative effects when used in } \\
\text { excess in isolation }\end{array}$ \\
\hline Madhura (Sweet) & $\begin{array}{l}\text { Add to the growth of all tissues, } \\
\text { Ojas and longevity. Soothing effect } \\
\text { on sense and mind promote strength } \\
\text { and complexions alleviate pitta, vata } \\
\text { and effects of poison. Relieve thirst } \\
\text { and burning sensation. Promote } \\
\text { healthy skin, hair, voice. Generally, } \\
\text { they are soothing, invigorating and } \\
\text { nourishing. They bring about } \\
\text { stability, healing of wound. They are } \\
\text { pleasant to nose, mouth, throat, lips } \\
\text { and useful in fits. They are unctuous, } \\
\text { cold, and heavy and liked by bees } \\
\text { and ants. }\end{array}$ & $\begin{array}{l}\text { Cause vitiation of Kapha resulting in } \\
\text { obesity, tenderness, laziness, } \\
\text { hyperanemia, heaviness loss of } \\
\text { appetite, loss of the power of } \\
\text { digestion, abnormal growth of } \\
\text { muscles in throat and mouth (neck } \\
\text { and face) difficulty in breathing, } \\
\text { cough, common cold, Alasaka (a } \\
\text { type of Ama dosa in GIT), fever } \\
\text { preceded with cold, sweetness in } \\
\text { mouth, vomiting, loss of sensation } \\
\text { (loss of consciousness?) and voice } \\
\text { etc. }\end{array}$ \\
\hline Amla (Sour) & $\begin{array}{l}\text { Add to the deliciousness of food, } \\
\text { stimulate appetite, nourish and } \\
\text { energise the body, enlighten the }\end{array}$ & $\begin{array}{l}\text { Cause thirst, morbid sensitiveness of } \\
\text { teeth, closure of eyes, horrifica tion, } \\
\text { liquification of Kapha, aggravation }\end{array}$ \\
\hline
\end{tabular}




\begin{tabular}{|c|c|c|}
\hline & $\begin{array}{l}\text { mind strengthen the sense organs, } \\
\text { promote strength, alleviate vata, } \\
\text { nourish the heart, cause salivation, } \\
\text { help in swallowing, moistening and } \\
\text { digestion of food. They are } \\
\text { refreshing light (Laghu), hot and } \\
\text { unctuous }\end{array}$ & $\begin{array}{l}\text { of Pitta, vitiation of Rakta, decorn- } \\
\text { position of muscle, flabbiness of the } \\
\text { body, oedema in patients suffering } \\
\text { from emaciation, consumption } \\
\text { cachexia and weakness, due to their } \\
\text { hotness cause unctuous suppuration } \\
\text { of wounds of varied origin. }\end{array}$ \\
\hline Lavana (Salt) & $\begin{array}{l}\text { Help in carination, moistering, } \\
\text { digestion, cutting, splitting and } \\
\text { withering away of unnecessary } \\
\text { material in the body. They are sharp, } \\
\text { mobile Vikasi and laxative. } \\
\text { Produces avakasa; Alleviate rata, } \\
\text { cures stiffness obstruction and } \\
\text { accumulation, nullifies all other } \\
\text { tastes, causes salivation, liquefies } \\
\text { kapha, clarifies the channels of } \\
\text { circulation, bring about tenderness } \\
\text { of all the bodily organs cause } \\
\text { deliciousness of food. It forms } \\
\text { essential ingredient of food. It is } \\
\text { neither very heavy,unctuous, not hot. }\end{array}$ & $\begin{array}{l}\text { Causes vitiation of Pitta Rakta, } \\
\text { thirst, fainting, hot sensation, } \\
\text { erosion, depletion of muscle tissue, } \\
\text { sloughing in the parts of the body } \\
\text { afflicted with obstinate skin diseases } \\
\text { including leprosy, aggravation of } \\
\text { poisonous symptoms, bursting of } \\
\text { inflamed parts, dislodge ment of } \\
\text { teeth, deficient manhood, } \\
\text { obstruction of the function of } \\
\text { manhood, obstruction of the function } \\
\text { of senses, pro duction of premature } \\
\text { wrinkling-grey hairs and baldness; } \\
\text { also causes diseases like Raktapitta } \\
\text { (bleeding disorder)Amla pitta } \\
\text { (hyperacidity), Visarpa (erysipelas), } \\
\text { Vicarcika skin disease), Indralupta } \\
\text { (alopecia) etc. }\end{array}$ \\
\hline Tikta (Bitter) & $\begin{array}{l}\text { This is not delicious by itself, but } \\
\text { added with other things, promotes } \\
\text { deliciousness. It is antitoxic and } \\
\text { germicidal. Cures fainting, burning } \\
\text { sensation, itching, obstinate skin } \\
\text { diseases including leprosy,thirst and } \\
\text { fever. Promotes firmness of skin and } \\
\text { muscles, digestion; purifies milk } \\
\text { (Stanya) helps in depletion of } \\
\text { moisture, fat, bone marrow, lymph, } \\
\text { pus, sweat, urine, stool, pitta and } \\
\text { kapha. It is cold, non-unctuous and } \\
\text { light }\end{array}$ & $\begin{array}{l}\text { Depletes plasma, blood, muscle fat, } \\
\text { bone marrow and Semen. Produces } \\
\text { roughness in the circula-tory } \\
\text { channels reducers, strength, causes } \\
\text { emacia-tion weariness, an } \\
\text { conciousness, giddiness, dryness of } \\
\text { mouth and causes diseases of vata. }\end{array}$ \\
\hline Katu (Pungent) & $\begin{array}{l}\text { Keeps the mouth clean, promotes } \\
\text { digestion, helps in the absorption of } \\
\text { food, and causes secretion through } \\
\text { nose lacrimation. Helps proper } \\
\text { action of senses, useful in obesity, } \\
\text { urticaria, and chronic conjunctivitis. } \\
\text { Eliminates waste products which are } \\
\text { sticky in nature, causes deliciousness } \\
\text { of food, cures itching, arrests } \\
\text { excessive spreading of ulcers, kills } \\
\text { germs, corrodes muscle tissues, } \\
\text { disintegrates blood clots other } \\
\text { obstructions, cleanses the passages } \\
\text { and alleviates kapha. It is light, hot } \\
\text { and non-unctuous }\end{array}$ & $\begin{array}{l}\text { Destroys manhood, causes } \\
\text { unconsciousness, weariness, } \\
\text { emaciation, choking giddiness, } \\
\text { burning sensation in throat, thirst } \\
\text { and diminution of strength tremor, } \\
\text { pain in legs hands, back etc }\end{array}$ \\
\hline Kasaya(Astringent) & $\begin{array}{l}\text { This is sedative and, constipative, } \\
\text { produces pressure on the affected } \\
\text { part and causes granulation, }\end{array}$ & $\begin{array}{l}\text { Causes dryness of mouth of the } \\
\text { heart, distension of abdomen, } \\
\text { obstruction of speech, constriction of }\end{array}$ \\
\hline
\end{tabular}




\begin{tabular}{|l|l|l|}
\hline & $\begin{array}{l}\text { absorption affiction } \\
\text { stiffess.Alleviates kapha and Rakta } \\
\text { pitta (bleeding disorder). Absorbs } \\
\text { body fluid and is dry, cold and } \\
\text { heavy. }\end{array}$ & $\begin{array}{l}\text { circulating channels, black } \\
\text { complexion, and destruction of } \\
\text { manhood. Gets digested slowly, } \\
\text { obstructs the passage of flatus, urine, } \\
\text { stool and semen, cause emaciation, } \\
\text { weariness, thirst, stiffness and pro- } \\
\text { duces diseases like hemi-plegia, } \\
\text { spasm, convulsion, facial paralysis } \\
\text { etc. }\end{array}$ \\
\hline
\end{tabular}

The concept of these six tastes (Rasa) forms one of the important foundations of Ayurveda pharmacology and biodynamics of drugs and food. Such an elaborate deliberation on 'Rasa' is not to be found in any ancient literature other than Ayurveda.

\section{Gandha Guna}

This is the natural property of Prthvi mahabhuta, perceivable only by Ghranendriya (nose). Gandha basically is Tanmatra in Guna form. Grosser evolutes of Gandha tanmatra is Prthvi mahabhuta. All physical matter possesses this guna and is perceivable to Ghranendriya (nose). Ayurveda finds this as very much useful and valid parameter to identify and standardize the drugs and also as a clinical method of examination of the patient. Although specific types of odour are not enumerated at one place, references to

different kinds of odour in different contexts are abundantly available in classical Ayurveda literature. The unique odour of garlic, asafoetida, Acorus calamus, musk, rose, santulum, sweat, urine faeces, blood etc are certainly helpful in identification of such materials.

Katu gandha, tiksna gandha, ugra gandha, laja gandha, visra gandha, lohagandha, amagandha, ajagandha, durgandha, sugandha are some of the types of gandha's that are commonly encountered in the Avurvedic literature. Odour plays an important role in clinical diagnosis and therefore it is considered as one of the clinical methods (under ghranendriya pariksa). Excessive use or abuse or misuse of Gandha guna (odour) amounts Asatmendriyartha Samyoga which can lead to many diseases.

\section{Gurvadi Gunas}

These 20 gunas are called Aharagunas or sariragunas as they are present in both food and body. These are not present only in food and body but also in Pancamahabhutas, the constituent factors of drug. Gunas are both physical and biophysical. The entire Samanya-Visesa concept revolves mainly round this category of Gunas. Medicinal herbs are also indentified on the basis of these Gunas. Many nomenclatures of drugs and diseases are after these Gunas, like sita-pitta-usnavata (diseases); kharasparsa, katutraya, etc. (drugs). Various therapies are described in terms of these gunas. Thus, the chapter on gunas in Ayurveda has wide ramifications. The biophysical aspect of these properties is inferred by the action they produce in the body subsequent to administration.

Table No 8:-Gurvadi Gunas and their Applied Aspects Gurvadi Gunas and Rasas

\begin{tabular}{|l|l|l|}
\hline Sr. No. & Rasas (Taste) & Predominant Gunn related to Rasa \\
\hline 1 & Madhura (sweet) & Guru (heavy), Sita (cold), Snigdha (unctuous) \\
\hline 2 & Amla (sour) & Laghu (light), Usna (hot), Snigdha (unctuous), Sara (flowing) \\
\hline 3 & Lavana (salt) & Guru (heavy), Urn (hot), Snigdha (unctuous), Sara (flowing) \\
\hline 4 & Tikta (bitter) & Laghu (light), Sita (cold), Ruksa \\
\hline 5 & Katu (pungent) & Laghu (light), Usna (hot), Ruksa \\
\hline 6 & Kasaya (astringent) & Ruksa, Sita (cold), Guru (heavy) \\
\hline
\end{tabular}

\section{Gurvadi Gunas and Mahabhutas}

\begin{tabular}{|l|l|l|}
\hline Sr. No. & Mahabhutas & Predominant Gunas related to Bhuta \\
\hline 1 & Prthvi & Gandha, Guru, Sthira, Kathina, Manda Khara, Sthula, Sandra \\
\hline 2 & Ap & $\begin{array}{l}\text { Rasa, Guru, Sita,Snigdha, Manda, Sara, Mrdu, Picchila, Sandra, } \\
\text { Drava }\end{array}$ \\
\hline 3 & Teja & Rupa, Laghu, Usna, Tiksna, Vitada, Slaksna, Suksma \\
\hline & Vayu & Sparsa, Suksma, Khara, Visada, Ruksa,Vyavaya \\
\hline
\end{tabular}




\begin{tabular}{|c|l|l}
\hline 5 & Akasa & Sabda, Laghu, Visada, Slaksna, Suksma, Vyavaya \\
\hline
\end{tabular}

Gurvadi Gunas and Dosas

\begin{tabular}{|l|l|l|}
\hline Sr. No. & Dosas & Predominant Gulas related to Dosas \\
\hline $\mathbf{1}$ & Vata & Ruksa, Laghu, Sita, Khara, Suksma, Cala, Visada \\
\hline $\mathbf{2}$ & Pitta & Usna, Snigdha, Tiksna, Laghu, Sara, Drava \\
\hline $\mathbf{3}$ & Kapha & Snigdha, Sita, Manda, Guru, Slaksna, Sthira, Picchila \\
\hline
\end{tabular}

Gurvadi Gunas and Dhatu.

\begin{tabular}{|l|l|l|}
\hline Sr.No. & Dhatu & Predominant Gum) related to Dhatu \\
\hline 1 & Rasa & Guru, Sita,Snigdha, Manda, Sara, Picchila,Sthula, Drava \\
\hline 2 & Rakta & Drava, Picchila, Mrdu, Sara, Tlksna, Snigdha, Usna, Guru \\
\hline 3 & Mamsa & Guru,Sita,Snigdha,Sthira Kathina_ Picchila \\
\hline 4 & Meda & Guru, Sita, Snigdha, Manda, Sara, Mrdu, Picchila, Drava \\
\hline 5 & Asthi & Guru, Usna, Manda,Sthira, Kathina, Visada, Khara \\
\hline 6 & Majja & Guru, Usna, Snigdha, Manda, Sara, Mrdu, Picchila, Drava \\
\hline 7 & Sukra & Guru, Sita, Snigdha, Sara, Mrdu, Picchila, Drava \\
\hline
\end{tabular}

Gurvadi Gunas and Upadhatu

\begin{tabular}{|c|l|l|}
\hline Sr. No. & Upadhatu & Predominant Gunas related to Upadhatu \\
\hline 1 & Stanya & Guru, Sita, Snigdha, Manda, Sara, Mrdu, Picchila, Drava \\
\hline 2 & Artava & Laghu, Usna, Tiksna, Drava \\
\hline 3 & Kandara and sira & Guru, Manda, Sthira, Kathina \\
\hline 4 & Vasa-tvak & $\begin{array}{l}\text { Guru, Sita, Snigdha, Manda, Sthira (Vasa-Sara), Mrdu - (Tvak- } \\
\text { Kathina) Picchila (Vasa), Drava (Vasa) }\end{array}$ \\
\hline 5 & Snayu & Guru, Sthira. Kathin \\
\hline
\end{tabular}

Gurvadi Gunas and Malas

\begin{tabular}{|c|l|l|}
\hline Sr. No. & Mala & Predominant Gunas related to Mala \\
\hline 1 & Purisa & Guru, Manda, Kathina, Visada, Sthula, Sandra \\
\hline 2 & Mutra & Drava, Picchila, Mrdu, Sara, Usna, Manda, Snigdha \\
\hline 3 & Sveda & Guru, Sita, Snigdha, Manda, Sara, Picchila, Drava \\
\hline 4 & Nakha-Kesa & Khara, Visada, Manda, Guru \\
\hline 5 & Kha-mala & Guru, Snigdha, Picchila \\
\hline
\end{tabular}

\begin{tabular}{|c|c|c|}
\hline Predominant Gunas & Ahara Drayas & Ausadha and Cikitsa karma \\
\hline Guru & $\begin{array}{l}\text { Curd, Buffalo's milk, Jackal fruit, } \\
\text { Mango, Masa, Payasa, Guda }\end{array}$ & $\begin{array}{l}\text { Gold, Iron, Palandu, , A tmagupta, } \\
\text { Satavari, Udumbara, Snehana, } \\
\text { Brmhana, Anuvasana }\end{array}$ \\
\hline Laghu & $\begin{array}{l}\text { Goat's milk, Takra, Jangala mamsa, } \\
\text { Saindhava lavana, Dhanyaka, } \\
\text { Dadima, Lemon, Jiraka, Tambula, } \\
\text { Kulattha, Mulaka,Surana, } \\
\text { Karavellaka, Patola, Nadeya jala, } \\
\text { Purana madhu }\end{array}$ & $\begin{array}{l}\text { Vid lavana, } \\
\text { Vanga,Tamra,Sunthi, , Pippali, } \\
\text { Katuki, Ajamoda, Ela, Datamula, } \\
\text { Langhana, Ruksana }\end{array}$ \\
\hline Sita & $\begin{array}{l}\text { Milk, Butter, Cow's ghee, } \\
\text { Sasa mamsa, Paravata } \\
\text { mamsa, Saindhava, Kadali } \\
\text { phala, Draksa, Godhuma, } \\
\text { Mudga }\end{array}$ & $\begin{array}{l}\text { Mukta, Pravala, Gairika, Gold, } \\
\text { Silver, Gems, Yatimadhu, Laksa, } \\
\text { Lavanga, Ela, Arjuna, } \\
\text { Kumari,Snehana, Brimhana, } \\
\text { Stambhana }\end{array}$ \\
\hline Usna & $\begin{array}{l}\text { Mesa ksira, Dadhi, Takra, } \\
\text { Kulattha, Matsya, Sarsapa } \\
\text { taila, Masa }\end{array}$ & $\begin{array}{l}\text { Gomutra, Kasturi, Silajita, , } \\
\text { Gandhaka, Haritaki, Vaca, Hingu, } \\
\text { Bibhitaki, Rasona }\end{array}$ \\
\hline
\end{tabular}




\begin{tabular}{|c|l|l|}
\hline \multirow{2}{*}{ Snigdha } & $\begin{array}{l}\text { Ksira, Navanita, Ghee, } \\
\text { Mamsa, Matsya, Lavana, } \\
\text { Kharjura, Sali, Godhuma, } \\
\text { Masa,Patola }\end{array}$ & $\begin{array}{l}\text { Rajata, Parada, Silajita, } \\
\text { Satavatri }\end{array}$ \\
\hline PredminantGunas & $\begin{array}{l}\text { Ahara dravyas } \\
\text { puga, Yava, Mudga, jangala } \\
\text { mamsa, Canaka, Masora, } \\
\text { Laja }\end{array}$ & $\begin{array}{l}\text { Ausadha and } \\
\text { Tankana, Purana madhu }\end{array}$ \\
\hline Tiksna & Sarsapa, Lasuna, Madya & $\begin{array}{l}\text { Gomutra, Marica, Bhallataka, } \\
\text { Hingu, Apamarga }\end{array}$ \\
\hline Sara & $\begin{array}{l}\text { Ksira Takra, Draksa, } \\
\text { Godhuma }\end{array}$ & $\begin{array}{l}\text { Gomutra, Rajata, Tamra } \\
\text { Gandhaka, Rasona, } \\
\text { Guggulu,Triphala }\end{array}$ \\
\hline Mrdu & $\begin{array}{l}\text { Ghrta, Ksira, Lavana, } \\
\text { Tandula }\end{array}$ & $\begin{array}{l}\text { Aragvadha, } \\
\text { Snehana,Stambhana, Brmhana }\end{array}$ \\
\hline Picchila & Anupa mamsa, Tila & $\begin{array}{l}\text { Guggulu, Kokilaksa, } \\
\text { Snehana,Brnhana }\end{array}$ \\
\hline Suksma & Lavana,Tila taila & Gomntra,Silajita,Svedana \\
\hline Slaksna & Lavana,Tila taila & Mukta, Pravala \\
\hline Sandra & Dadhi, Navanita & $\begin{array}{l}\text { Gomutra,Decocidons, } \\
\text { Arista }\end{array}$ \\
\hline Drava & Jala, Ksira, Taila, Takra & Puga, Khadira, Madya \\
\hline Vyavaya & &
\end{tabular}

\section{Additional Gunas as per Susruta}

Susruta has considred more than 20 Gunas. Sugandha and Durgandha are counted among Sabdadi special properties hence they are repetetions here. The remaining three (Vyavayi etc.) are necessary as they are some special attributes and found in certain Dravyas. Apart from these, other Gunas also are considered here and there, according to necessity. However, those properties enumerated above are very common and therefore they have been described here. Susruta does not define Gunas while he describes each Gunas with reference to physiological actions attributed to them, which is not found in Caraka Sarnhita.

\section{Gunas: A Comparative Reflection}

As regards the study of Gunas, it may be said that Acaryas had studied Gunas with reference to food articles, medicinal herband mineral, bodily elements (Dosa - Dhatu - Mala) both in healthy and unhealthy conditions, Pancamahabhutas, Rasa (tastes) of dravyas etc. with a view to determine the exact drug or food to be administered in a given condition of the body, based on Samanya visesa theory and also with a view to Identify the drugs - food articles and diseases.

Vaisesika Darsana has not considered Laghu, Sita, Usna, Ruksa, Manda, Ttksna, Sthira, Sara, Mrdu, Kathina, Picchila, Visada, Slaksna, Khara, Sthula, Suksma, Sandra, Drava, Vyavayi, Vikasi and Asu gunas seperately and independently although a few of these are mentioned by the Bhasyakara of Prasastapada.

Table No 9:-Comparative View of Gunas in Ayurveda and Vaisesika Philosophy

\begin{tabular}{|l|l|c|c|c|c|}
\hline Sr. No. & Gunas & $\begin{array}{l}\text { Caraka } \\
\text { Samhita }\end{array}$ & Susruta Samhita & $\begin{array}{l}\text { Vaisesika } \\
\text { Sutra }\end{array}$ & $\begin{array}{l}\text { Prasastapada's Padartha } \\
\text { Dharma Samgraha. }\end{array}$ \\
\hline 1 & Sabda & + & + & - & + \\
\hline 2 & Sparsa & + & + & + & + \\
\hline 3 & Rupa & + & + & + & + \\
\hline 4 & Rasa & + & + & + & + \\
\hline 5 & Gandha & + & + & + & + \\
\hline 6 & Guru & + & + & - & + \\
\hline 7 & Laghu & + & + & - & + \\
\hline 8 & Sita & + & + & - & - \\
\hline
\end{tabular}




\begin{tabular}{|c|c|c|c|c|c|}
\hline 9 & Usna & + & + & - & - \\
\hline 10 & Snigdha & + & + & - & Sneha \\
\hline 11 & Ruksa & + & + & - & - \\
\hline 12 & Manda & + & + & - & - \\
\hline 13 & Tiksna & + & + & - & - \\
\hline 14 & Sthira & + & + & - & - \\
\hline 15 & Sara & + & + & - & - \\
\hline 16 & Mrdu & + & + & - & - \\
\hline 17 & Kathina & + & + & - & - \\
\hline 18 & Visada & + & + & - & - \\
\hline 19 & Picchila & + & + & - & - \\
\hline 20 & Khara & + & Karkasa & - & - \\
\hline 21 & Sthula & + & + & - & - \\
\hline 22 & Suksma & + & + & - & - \\
\hline 23 & Sandra & + & + & - & - \\
\hline 24 & Drava & + & + & - & + \\
\hline 25 & Buddhi & + & + & + & + \\
\hline 26 & Iccha & + & + & + & + \\
\hline 27 & Dvesa & + & + & + & + \\
\hline 28 & Sukha & + & + & + & + \\
\hline 29 & Duhkha & + & + & + & + \\
\hline 30 & Prayatna & + & + & + & + \\
\hline 31 & Para & + & - & + & + \\
\hline 32 & Apara & + & - & + & + \\
\hline 33 & Yukti & + & - & + & + \\
\hline 34 & Sankhya & + & - & + & + \\
\hline 35 & Samyoga & + & - & + & + \\
\hline 36 & Vibhaga & + & - & + & + \\
\hline 37 & Prithaktva & + & - & + & + \\
\hline 38 & Parimana & + & - & + & + \\
\hline 39 & Samskara & + & - & - & + \\
\hline 40 & Abhyasa & + & - & - & - \\
\hline 41 & Adrsta & - & - & - & + \\
\hline 42 & Vyavayi & - & + & - & - \\
\hline 43 & Vikasi & - & + & - & - \\
\hline 44 & Asukari & - & + & - & - \\
\hline
\end{tabular}

The above table shows the concept of Gunas in Ayurveda was much more advanced as are applicable topphysical matters from the utility point of view.

\section{Buddhyadi Gunas}

These are the characteristic psychic features attributed to Karma purusa/Sthulaplow, as the express manifestation of these psychic qualities are traceable only in purusa associated with mind and PancabhautikaSarira.

The term Buddhi (intellect) is very comprehensive so as to include Smrti (memory), Cetana (consciousness), Dhrti (tolerance) and Ahankara (ego) etc. which are stated to be features of Paramatma (bhutatma in this context but not in the sense of the term Paramatma in Bhagvadgita) i.e. absolute soul.

Icchadvesahsukhamduhkhamprayatnascetanadhrtih!

Buddhiljsmrtirahankarolinganiparamatmanah (Ch.Sh.1.72)

Iha cetanadinambuddhigrahanaivagrahanam (ChSu.1.49, Cakrapani)

In addition to the above, the desire (iccha); hatred (dvesa); happiness (sukha); misery (duhkha); efforts (prayatna) are also considered as qualitiy. The knowledge of these Gunas apparently looking spiritual in nature is no less important in Ayurveda, a holistic health science. These qualities have definite role in influencing mental health. 
They influence Rajoguna\&Tamoguna which are considered as Manodosas (psychic vitiaters) and thus create health problems. The description of Sadvritta/Sadacara (right conduct) in almost all ancient Ayurveda literature is aimed to tune these qualities suitable to maintain good mental health.

\section{ParadiGunas}

\section{Para \&Apara (superior and infeior)}

These two terms are indicating the degree of relative quality. They are used to indicate the qualitative superiority or inferiority of a region (a desert is superior to marshy land), season, (Visargakaia is superior to Adanakala), age (youth to other ages) measurement (normal measurement desribed to other measurements), potency-Vipaka-taste of a durg etc. In other words, a Dravya that is qualitatively superior is more conducive to health and one that is inferior is not so much conducive to health.

\section{Yukti}

This is different from the 'Yukti' pariksa, described earlier. Here, this is enumerated as a Guna, which means proper application of therapy in an appropriate condition. The success of treatment depends on Yukti which in turn depends on fixation of proper dosage (posology) and time of administration.

\section{Sankhya}

Computation: Caraka enumerates number of Dosas, Dhatus and Malas, diseases and their types. Computation is also used in classifying diseases like 80 Vata vyadhis, 40 Pitta vyadhis and 20 Kapha vyadhis; drugs like triphala (three fruits) pancamala (five roots of common action) etc. in the nomenclature of drug like Trikantaka, pancangula (five fingers), Saptaparni (having seven leaves a compound leaf etc). Thus it is widely employed in Ayurveda, while Vaisesika Darsana does not mention any of its applications.

\section{Samyoga}

Amalgamation of two or more than two things is Samyoga. This can be Nitya or Anitya (temporary).

Samyoga is of 3 types as

Table No 10:-

Types of Saroyoga (Amalgamation)

\begin{tabular}{|l|l|l|}
\hline $\begin{array}{l}\text { Eka karmaja (amalgamation of } \\
\text { drugs possessing similar action) } \\
\text { [Eg : Mixing all Diuretics or all } \\
\text { digestives like Goksuradi carna } \\
\text { Asta carna] }\end{array}$ & $\begin{array}{l}\text { Dvandva karmaja } \\
\text { (amalgamation of drugs } \\
\text { possessing two opposite }\end{array}$ & $\begin{array}{l}\text { Sarva karmaja (amalgamation } \\
\text { of drugs of multiple action) } \\
\text { [Eg : A preparation possessing }\end{array}$ \\
action) & $\begin{array}{l}\text { Eg : Combination of } \\
\text { Emetics and Purgatives in } \\
\text { a single preparation] }\end{array}$ & $\begin{array}{l}\text { Blood purifier etc - Litaliser } \\
\text { Cyavanaprasa] }\end{array}$ \\
\hline
\end{tabular}

Types of Samyoga

(Amalgamation)

\begin{tabular}{|l|l|}
\hline $\begin{array}{l}\text { Nitya } \\
\text { (chemical combination) }\end{array}$ & $\begin{array}{l}\text { Anitya } \\
\text { (physical combination) }\end{array}$ \\
\hline
\end{tabular}

This Samyoga is meant to enhance or to reduce the potency of 1 drug. To enhance the potency of a drug, drugs of similar action are to be added.This also depends on the status of a disease. The combination should be such, as to make it acceptable to the patient in terms of its taste, colour, touch and smell. In order to achieve this even drugs of opposing qualities or actions are to be combined.

In Vaisesika Darsana, Samyoga is more physical and general, while the same in Ayurveda is meant to achieve a desired Pharmacological effect in a given therapy. This may be found in causitive factors of a disease, as also in Dosas. Nitya samyoga stands for chemical combination and Anitiya for physical mixture. 


\section{Vibhaga}

Removal or separation of a thing present in a combination. In order to have the desired effect or to banish some unwanted action or to enhance the action or to enhance the action of a drug some inhibitor in it may have to be separated. This is Vibhaga, and is different from Vaisesika Darsana in so for as applied aspects are concerned.

\section{Prthaktva}

Individuality - special features which enable to distinguish one from another, and suggest plurality.

\section{Parimana}

This refers to measurement. It is very essential to know exact proportion of each drug in a compound preparation, which is measurable. The degree of success of elimination therapies like Vamana, Virecana etc, is assessed on the basis of measureable quantity of vomitus or feacal discharge. The dosage is fixed in proportion to the degree of vitiation of Dosas. The bodily elements have measurable quantity. The fluids like blood, lymph, urine, etc. are measured in anjali (Angulimeya). In many diseases, decreased or increased bodily elements are the characteristic features like in Prameha-prabhuta mutrata (profuse urine) in Matraksaya - scanty urine; and in Pandu Alpa rakta (decreased blood). Therefore, this Guna is widely useful in diagnosis, pharmaceutical preparation and therapeutic administration of drugs.

Although Vaisesika Darsana deals with this aspect the pertinence is altogether different. The classification like Anu, Mahat, Dirgha and Hrasva also finds it's place in Ayurveda. Classification of nitya-anitya is not specifically mentioned in Ayurveda. Ayurveda has considered subdivision of anitya which has more relevance to any science, especially medical science.

\section{Samskara (Metamorphosis)}

Processes which bring about change in natural qualities of dravya are meant here. Food and medicines are prepared through some processes like washing, churning, milling, soaking etc. which influence the quality of the products. The medicinal potency is increased by certain process like Svedana, Mardana, Murcchana etc. processes, which help to remove, physical-chemical impurities and enhance the potency of mercury are also Samskaras. Any process using heat/water or both, to bring about change in quality to the extent possible is Samskara according to Ayurveda.Kanada has not mentioned this, but Prasastapada has described 3 types of Samskara which has wider connotation than Ayurveda Samsakara. Ayurveda considers that certain qualities can be changed or converted by processes while Vaisesika Darsana considers properties as non-convertibles. Non-convertibility of Gunas is certainly acceptable to Ayurveda as far as original Gunas of Mahabhuta (Maha gunas are nonconvertible) are concerned.

\section{Abhyasa (Practice)}

Continuous use of anything is Abhyasa. Any diet or drug, exercise etc. to show their good or bad effect will have to be necessarily taken continuously. A habit is a habit only when something is indulged in, continuously. This is useful especially in treatment. Consumption of wholesome food and medicine, continuously for a pre-determined time, alone can cause disintegration of chain of vitiated dosas and growth of new fresh non vitiated dosas and dhatus (tissue elements) resulting in a state of perfect health. (C.Su.12;C.Su.23/3;C.Su.16/36, C.Su.26/34.)

These 10 Paradi qualities are not only applicable in Ayurveda, but are applicable in any other branch of knowledge.

Table No 11:-showing the Paradi gunas in different schools

\begin{tabular}{|l|c|c|c|}
\hline Gunas & Caraka & Susruta & Vaisesika \\
\hline Para & + & & + \\
\hline Apara & + & & + \\
\hline Yukti & + & & - \\
\hline Sankhya & + & \multirow{2}{*}{ Not specifically mentioned as such } & + \\
\hline Samyoga & + & & + \\
\hline Vibhaga & + & & + \\
\hline Prthaktva & + & & + \\
\hline Parimana & + & & + \\
\hline Samskara & + & & - \\
\hline Abhyasa & + & & + \\
\hline
\end{tabular}




\section{References:-}

1. Vagbhata, Ashtangaangraha, Commentary by Gupta KA, Sutrasthan, 3/65. Varanasi: ChaukhambhaKrishnadas Academy; 2005.

2. Agnivesh, Charaka, Dhridhabala, Chakrapani. In: Trikamaji VJ, Editor CharakasamhitaSharirsthan, Varanasi: ChaukhambhaOrientaliya.

3. Agnivesh, Charaka, Dhridhabala, Chakrapani. In: Trikamaji VJ, Editor CharakasamhitaSharirsthan, Varanasi: ChaukhambhaOrientaliya.

4. YogacharyaKrushnajiKeshavKolhatkar, Bharatiya Manasshastra, Sarth and Saviviran, PatanjalYogdarshan. P. 383

5. Madhavacharya, the Sarva-Darsha-Samgraha, Edited by Dr. Uma Shankar Sharma 'Rishi" ChaumkhambaVidyabahawan, Varanasi, P.555

6. Acharya Rajkumar Jain, Yogaur Ayurved, Pranavaya (Jainayurveda) ShodhSansthan, P.29

7. Padambhushan Acharya BaldevaUpadhyaya forwarded by M.M. GopinathKaviraja, Bharatiya Darshana, SharadaMandir, Varanasi, P.304

8. S.V. Shukla, Ayurved Darshana, ChaukhambaOrientalia, Varanasi, P. 120

9. Susruta, Dalhana, Susrut Samhita Sutra Sthana, ChuukhambhaOrientaliya. p.no. 6-7

10. Agnivesh, Charaka, Dhridhabala, Chakrapani. In: Trikamaji VJ, Editor Charakasamhita (Poorwardha), Varanasi: ChaukhambhaOrientaliya. p.no. 189

11. Agnivesh, Charaka, Dhridhabala, Chakrapani. In: Trikamaji VJ, Editor CharakasamhitaSharirsthan, Varanasi: ChaukhambhaOrientaliya. p.no. 378

12. Susruta, Dalhana, Susrut Samhita ChikitsaSthana, ChuukhambhaOrientaliya. p.no. 27

13. Agnivesh, Charaka, Dhridhabala, Chakrapani. In: Trikamaji VJ, Editor CharakasamhitaSharirsthan, Varanasi: ChaukhambhaOrientaliya. p. no. 377

14. Sharangdhar, Sharangdhara Samhita, Volume-I, ChaukhambhaSurbharati, Varanasi. p.no.20

15. Agnivesh, Charaka, Dhridhabala, Chakrapani. In: Trikamaji VJ, Editor CharakasamhitaSharirsthan, Varanasi: ChaukhambhaOrientaliya. p. no. 385

16. Susruta, Dalhana, Susrut Samhita ChikitsaSthana, ChuukhambhaOrientaliya. p.no. 27

17. Agnivesh, Charaka, Dhridhabala, Chakrapani. In: Trikamaji VJ, Editor CharakasamhitaSharirsthan, Varanasi: ChaukhambhaOrientaliya. p.no.389

18. Ayurved Darshana, Chaukhamba Orientalia, Varanasi, P. 120 